\title{
Growth, yield, and postharvest quality in eggplant produced under different foliar fertilizer (Spirulina platensis) treatments
}

\author{
Crescimento, produção e qualidade pós-colheita de berinjela \\ produzida sob adubação foliar com Spirulina platensis
}

\author{
George Alves Dias ${ }^{1}$; Railene Hérica Carlos Rocha ${ }^{2 *}$; Josinaldo Lopes Araújo \\ José Franciraldo de Lima ${ }^{4}$; Wellinghton Alves Guedes ${ }^{5}$
}

\begin{abstract}
This study evaluated the growth, yield, and postharvest quality of eggplant grown under different foliar fertilizer treatments with Spirufert ${ }^{\circledR}$ (Spirulina platensis). The treatments consisted of four fertilizer concentrations applied at four phenological stages: $\mathrm{M} 1\left(10,15,25\right.$, and $\left.35 \mathrm{~g} \mathrm{~L}^{-1}\right), \mathrm{M} 2(15,20,30$, and $\left.40 \mathrm{~g} \mathrm{~L}^{-1}\right), \mathrm{M} 3\left(20,25,35\right.$, and $\left.45 \mathrm{~g} \mathrm{~L}^{-1}\right)$, and M4 (control plants, water spraying only). For Postharvest experiments were conducted in a $4 \times 5$ factorial design corresponding to the four treatments in the field experiment and five storage times. Spirufert ${ }^{\circledR}$ applied at lower concentrations (M1) resulted in greater fruit yield without affecting the foliar concentrations of N, P, K, and Na. Higher fertilizer concentrations (M3) increased vegetative growth but reduced eggplant yield. Fruit color parameters and soluble solids contents were not affected by fertilizer application, but pulp firmness was more stable in M1 fruits stored for up to six days.
\end{abstract}

Key words: Solanum melongena. Microalgae. Biofertilizer. Postharvest conservation.

\section{Resumo}

Objetivou-se avaliar o crescimento, a produção e a qualidade pós-colheita da berinjela em função de manejos (M) de aplicação foliar com Spirufert ${ }^{\circledR}$ (Spirulina platensis). Os manejos foram constituídos por quatro concentrações do produto, aplicadas em quatro fases fenológicas da cultura, sendo o M1 constituído por pulverizações nas concentrações de $10,15,25$ e $35 \mathrm{~g} \mathrm{~L}^{-1}$; o $\mathrm{M} 2$ correspondeu às concentrações de $15,20,30$ e $40 \mathrm{~g} \mathrm{~L}^{-1}$; o $\mathrm{M} 3$ por 20, 25, 35 e $45 \mathrm{e} \mathrm{g} \mathrm{L} \mathrm{L}^{-1}$ e o $\mathrm{M} 4$ correspondeu à testemunha. Para o ensaio de pós-colheita, os tratamentos corresponderam a um esquema fatorial 4 x 5 , correspondente aos quatro tratamentos originados do experimento de campo e cinco períodos de armazenamento. O Spirufert ${ }^{\circledR}$ aplicado em concentrações mais baixas (M1) proporciona maior produção de frutos, sem influenciar os teores foliares de N, P, K e Na da cultura. Concentrações mais elevadas do produto (M3) favorecem o desenvolvimento vegetativo da berinjela em detrimento da produção. O produto não afeta a cor do fruto nem seus sólidos solúveis, porém o manejo M1 proporciona maior estabilidade na firmeza dos frutos durante o seu armazenamento de até seis dias.

Palavras-chave: Solanum melongena. Microalga. Biofertilizante. Conservação pós-colheita.

${ }^{1}$ Discente do Curso de Graduação em Agronomia, Universidade Federal de Campina Grande, UFCG, Pombal, PB, Brasil. E-mail: george.alves.dias@hotmail.com

2 Prof ${ }^{\mathrm{a}}$ Dr ${ }^{\mathrm{a}}$ Fitotecnia, UFCG, Pombal, PB, Brasil. E-mail: raileneherica@ccta.ufcg.edu.br

3 Prof. Dr. Fertilidade de Solos, UFCG, Pombal, PB, Brasil.jhosinal_araujo@gmail.com

${ }^{4}$ Pesquisador, Doutor em Biotecnologia, Instituto Fazenda Tamanduá, Santa Teresinha, PB, Brasil. E-mail: josefranciraldo@, gmail.com

5 Discente do Curso de Mestrado em Horticultura Tropical, UFCG, Pombal, PB, Brasil. E-mail: wellinghton_guedes@hotmail. com

Author for correspondence 


\section{Introduction}

In recent years, consumption of eggplant (Solanum melongena L.) has increased considerably due to its medicinal properties (GONÇALVES et al., 2006; RAIGÓN et al., 2008), mainly because of its cholesterol-reducing properties (JORGE et al., 1998) and hypoglycemic effect (DERIVI et al., 2002). Eggplants are rich in vitamins B1 and B2 and minerals including calcium, phosphorus, iron, and potassium (RIBEIRO et al., 1998).

To meet the increased demand for eggplant fruits, investment in research is crucial to improve yield and postharvest fruit quality. Fertilizer management one of the main factors responsible for eggplant quality and yield (MANFIO, 2007; CARDOSO et al., 2008). Fertilization of eggplant cultures is usually done using mineral fertilizers, whose doses and application times are dependent on expected yield and plant phenology, respectively. According to Manfio (2007), eggplant nutrient requirements increase with plant growth and development and are maximized during flowering, fruit formation, and growth. However, as with other vegetable crops grown using conventional cultural practices, excessive fertilization of eggplant cultures can lead to several problems including soluble solids accumulation in the soil and nutrient leaching (CARDOSO et al., 2008). Thus, there is a growing need to develop environmentally friendly strategies for sustainable culturing of horticultural crops with high yields and less environmental damage.

Currently, the use of microalgae in agriculture, especially as biofertilizers or biostimulants, has attracted the interest of producers aiming to improve the productive performance of cultivated plants (CHOJNACKA et al., 2012). Microalgae are a large, diverse group of organisms that are classified mainly by their pigmentation, life cycle, and cell structure. Spirulina platensis is one of the main algae species used commercially (SCHMITZ et al., 2012). In its commercial form, S. platensis has a number of organic and inorganic compounds that indicate that this microalga species has a high potential as a biofertilizer (PRIYADARSHANI; RATH, 2012; MANRICH et al., 2014).

Because of the potential of microalgae for use in more sustainable production systems such as organic agriculture and biodynamic agriculture, a number of studies were conducted to evaluate the effect of microalgae fertilizers on different crops (ZODAPE et al., 2011; PAUDEL et al., 2012; SHALABY; EL-RAMADY, 2014; TARRAF et al., 2015; GARCIA-GONZALEZ; SOMMERFELD, 2015). Some of these studies have found a positive effect of microalgae fertilizers, especially when applied to leaves, in crops such as Allium sativum (SHALABY; EL-RAMADY, 2014), pepper (ALY; ESSAWY, 2008), rice (PAUDEL et al., 2012), and tomato (ZODAPE et al., 2011). Ferrazza and Simonetti (2010) reported that foliar application of marine algae (Ascophyllum nodosum) increased soybean grain weight. However, field studies with Spirulina platensis are scarce and were conducted mainly on horticultural crops. Oliveira et al. (2013) reported increased beet yield (fresh and dry matter) following foliar application of a $S$. platensis fertilizer under field conditions. Foliar application of $S$. platensis on pepper under field conditions in Egypt resulted in productivity similar to that with standard NPK fertilization (ALY; ESSAWY, 2008).

This study evaluated the growth, yield, and postharvest quality of eggplants grown under different foliar fertilizer treatments with Spirufert ${ }^{\circledR}$ (Spirulina platensis).

\section{Material and Methods}

The study consisted of field and laboratory experiments. Fieldwork was conducted from October 2014 to January 2015 at the Centro de Ciências e Tecnologia de Alimentos (CCTA), Universidade Federal de Campina Grande (UFCG), Pombal, Paraíba, Brazil. Eggplant seedlings of cultivar Embu were produced in a greenhouse using 200-cell polystyrene trays filled with commercial 
substrate (Baseplant $\left.{ }^{\circledR}\right)$. Seedlings were transplanted to the field at 24 days after sowing (DAS). Soil preparation consisted of plowing and harrowing to a $20 \mathrm{~cm}$ depth followed by windrowing to a 20 $\mathrm{cm}$ height and $100 \mathrm{~cm}$ width prior to planting. Soil samples were collected at planting and at the end of the study for soil characterization (Table 1), according to the methodology recommended by EMBRAPA (1997).

Table 1. Pre- and post-experiment soil physicochemical properties in the experimental area and irrigation water chemical properties. UFCG, Pombal 2015.

\begin{tabular}{|c|c|c|c|}
\hline Variable & Pre-experiment & Post-experiment & Irrigation water \\
\hline $\mathrm{pH}_{\mathrm{H} 2 \mathrm{O}}$ & 6.71 & 6.54 & 7.28 \\
\hline $\mathrm{EC}\left(\mathrm{dSm}^{-1}\right)$ & 0.9 & 0.05 & 0.23 \\
\hline $\mathrm{N}\left(\mathrm{gkg}^{-1}\right)$ & 1.62 & 0.94 & - \\
\hline $\mathrm{P}\left(\mathrm{mg} \mathrm{kg}^{-1}\right)$ & 32.0 & 23.5 & - \\
\hline $\mathrm{K}^{+}\left(\mathrm{cmol}_{\mathrm{dm}}^{-3}\right)$ & 0.24 & 0.34 & 0.016 \\
\hline $\mathrm{Ca}^{2+}\left(\mathrm{cmol}_{\mathrm{c}} \mathrm{dm}^{-3}\right)$ & 5.75 & 6.0 & 0.031 \\
\hline $\mathrm{Mg}^{2+}\left(\mathrm{cmol}_{\mathrm{c}} \mathrm{dm}^{-3}\right)$ & 5.28 & 5.32 & 0.069 \\
\hline $\mathrm{Na}^{+}\left(\mathrm{cmol}_{\mathrm{c}} \mathrm{dm}^{-3}\right)$ & 0.27 & 0.44 & 0.082 \\
\hline $\mathrm{SO}_{4}^{2-}\left(\mathrm{mmol}_{\mathrm{c}} \mathrm{dm}^{-3}\right)$ & - & - & 0.63 \\
\hline $\mathrm{CO}_{3}^{2-}\left(\mathrm{mmol}_{\mathrm{c}}^{\mathrm{c}} \mathrm{dm}^{-3}\right)$ & - & - & 0.0 \\
\hline $\mathrm{HCO}_{3}{ }^{2-}\left(\mathrm{mmol}_{\mathrm{c}} \mathrm{dm}^{3}\right)$ & & & 1.00 \\
\hline $\mathrm{Cl}^{-}\left(\mathrm{mmol}_{\mathrm{c}} \mathrm{dm}^{-3}\right)$ & - & - & 1.25 \\
\hline SAR & - & - & 1.15 \\
\hline $\mathrm{BS}\left(\mathrm{cmol}_{\mathrm{c}} \mathrm{dm}^{-3}\right)$ & 12.5 & 12.3 & - \\
\hline $\operatorname{CEC}\left(\mathrm{cmol}_{\mathrm{c}} \mathrm{dm}^{-3}\right)$ & 13.27 & 14.41 & - \\
\hline $\mathrm{V}(\%)$ & 94.5 & 85.6 & - \\
\hline $\operatorname{ESP}(\%)$ & 2.04 & 2.04 & - \\
\hline $\mathrm{OM}\left(\mathrm{g} \mathrm{kg}^{-1}\right)$ & 27.9 & 16.5 & - \\
\hline sand $\left(\mathrm{gkg}^{-1}\right)$ & 748 & - & - \\
\hline silt $\left(\mathrm{gkg}^{-1}\right)$ & 146 & - & - \\
\hline clay $\left(\mathrm{gkg}^{-1}\right)$ & 106 & - & - \\
\hline $\mathrm{D}_{\mathrm{ap}}\left(\mathrm{gcm}^{-3}\right)$ & 1.26 & - & - \\
\hline $\mathrm{D}_{\mathrm{t}}\left(\mathrm{gcm}^{-3}\right)$ & 2.5 & - & - \\
\hline porosity $\left(\mathrm{m}^{3} \mathrm{~m}^{-3}\right)$ & 0.53 & - & - \\
\hline
\end{tabular}

$\mathrm{P}, \mathrm{K}^{+}$, and $\mathrm{Na}^{+}$: Mehlich 1 extraction; $\mathrm{Ca}^{+2}$ and $\mathrm{Mg}^{+2}: \mathrm{KCl} 1 \mathrm{~mol} \mathrm{~L}^{-1}$ extraction. OM: soil organic matter; $\mathrm{CEC}(\mathrm{T})$ : cation exchange capacity at $\mathrm{pH} 7.0 ; \mathrm{V}=$ base saturation index; ESP: exchangeable sodium percentage; SAR: sodium adsorption ratio. Granulometric analysis by the Bouyoucos hydrometer method. $\mathrm{D}_{\mathrm{ap}}$ : apparent density by the $100-\mathrm{mL}$ cylinder method; $\mathrm{D}_{\mathrm{t}}$ : true density by the volumetric flask method.

The field experiment was four treatments and three blocks of a randomized complete block. Treatments consisted of four increasing dosages of foliar fertilizer Spirufert®. Each treatment (M) consisted of four fertilizer concentrations: M1 (10, 15,25 , and $\left.35 \mathrm{~g} \mathrm{~L}^{-1}\right), \mathrm{M} 2\left(15,20,30\right.$, and $\left.40 \mathrm{~g} \mathrm{~L}^{-1}\right)$, M3 (20, 25, 35, and $\left.45 \mathrm{~g} \mathrm{~L}^{-1}\right)$, and M4 (control treatment: plants sprayed with water only). Each plot had an area of $21 \mathrm{~m}^{2}$ and 24 plants (six useful plants; border plants were not included in the analysis), totaling 288 plants and an experimental area of $422.5 \mathrm{~m}^{2}$. Plants were transplanted at a $1.0 \times 1.5 \mathrm{~m}$ spacing using a vertical support system. Plants were irrigated by drip irrigation at a frequency of three waterings/day and $15 \mathrm{~min} /$ watering, maintaining the soil at field capacity.

Spirufert ${ }^{\circledR}$ application was done by foliar spraying using a 20-L knapsack sprayer and started 
at 10 days after transplanting (DAT). All treatments followed a five-day application interval. The first fertilizer dose was applied five times, before flowering; the second dose was applied twice during full flowering, the third dose was applied twice during fruit formation, and the fourth dose was applied repeatedly until fruits reached the optimal harvest point.

At the time of flowering (66 DAT), newlymature leaves were sampled for determination of $\mathrm{N}, \mathrm{P}, \mathrm{K}$, and $\mathrm{Na}$ levels according to the procedures described by Malavolta et al. (1997). Fruits were harvested at 73 DAT. The following variables were recorded at the time of harvest: number of leaves $(\mathrm{NL})>3 \mathrm{~cm}$; stem diameter (SD) at $10 \mathrm{~cm}$ from the plant collar using a digital caliper; plant height $(\mathrm{PH})$ from the collar to the plant apex; total number of flower buds (NFB), number of fruits (NF), plant yield, longitudinal diameter (LD) and equatorial diameter (DT) of fruits determined from the apex to the base and at the equatorial region, respectively.

After harvest, fruits from each treatment were selected for the postharvest experiment based on their uniformity in size and color. Fruits were taken to the laboratory, sorted by treatment, washed in running water, and placed on a bench at $22 \pm 5$ ${ }^{\circ} \mathrm{C}$ and $55 \pm 3 \% \mathrm{RH}$. Fruits were analyzed at 0,3 , 4,5 , and 6 days of storage in a 4 x 5 completely randomized factorial design corresponding to the four Spirufert ${ }^{\circledR}$ treatments in the field experiment and five storage times with three replicates.

Fruit color parameters, fruit firmness, and soluble solids contents were evaluated at each storage time. Color parameters were determined by two readings taken at the equatorial region of fruits using a CR-400 chroma meter (Konica Minolta, Tokyo, Japan) by the $\mathrm{L}^{*} \mathrm{a} * \mathrm{~b}$ * color space. Calibration was performed using a standard white plate following the manufacturer's instructions. The color parameters measured relative to the standard plate were lightness $\left(\mathrm{L}^{*}\right)$, which ranges from black (0) to white (100); a*, which ranges from green (-60) to red $(+60)$; and $b^{*}$, which ranges from blue $(-60)$ to yellow $(+60) . L^{*}, a^{*}$, and $b^{*}$ values were used to calculate hue angle, ${ }^{\circ} \mathrm{h}^{*}\left({ }^{\circ} \mathrm{h}^{*}=\operatorname{arctang}\left(\mathrm{a}^{*} / \mathrm{b}^{*}\right)\right.$ $(-1)+90$, for negative $a^{*}$ values and ${ }^{\circ} \mathrm{h}^{*}=90$ $\operatorname{arctang}\left(\mathrm{a}^{*} / \mathrm{b}^{*}\right)$, for positive $\mathrm{a}^{*}$ values) and chroma saturation index, $\mathrm{C}^{*}\left(\mathrm{C}^{*}=\mathrm{a}^{* 2}+\mathrm{b}^{* 2}\right)^{1 / 2}$ (PINHEIRO, 2009). Pulp firmness was determined after removing the skin with an 8 -mm blade according to the Association of Official Analytical Chemists (AOAC, 2005). Soluble solids (SS) contents were determined directly from homogenized juice using a PR-100 Palette digital refractometer (Atago Co., Ltd., Tokyo, Japan), according to the recommendations of the Association of Official Analytical Chemists (AOAC, 2005).

Data were analyzed using analysis of variance (ANOVA) and the Tukey's test for comparison of means at the 5\% significance level. All analyzes were performed using SISVAR software (FERREIRA, 2011).

\section{Results and Discussion}

Eggplant growth, as measured by $\mathrm{SD}$ and $\mathrm{PH}$, was not affected by the different Spirufert ${ }^{\circledR}$ treatments (Table 2). Conversely, the number of fruits was significantly higher in Spirufert $\mathbb{R}$ treatments M1, M2, and M3 than in control (M4) plants, even though the dose-response relationship was not linear (Table 2). In addition, the number of flower buds and fruit yield were lower in treatment M3, which corresponded to the highest increasing fertilizer concentrations.

Because treatment M3 had the highest fertilizer concentrations, its adverse effect on eggplant yield may have been caused by the stimulating effect of Spirufert ${ }^{\circledR}$ on vegetative growth, given its high nitrogen concentration (Table 2). In fact, Maldaner et al. (2009) observed that the increase in the number of eggplant leaves is associated with the development of some vegetative organs and the expansion of leaf area, which intercepts the solar radiation used in photosynthesis for biomass 
accumulation, triggering intraspecific competition for water, light, and nutrients that may adversely affect fruit yield. The positive effect of Spirufert ${ }^{\circledR}$ on yield observed in treatments M1 and M2 may also be related to a non-nutritional effect of $S$. platensis, considering that microalgae are rich in polypeptides, amino acids, hormones, organic acids, vitamins, and enzymes that could act as growth promoters (MANRICH et al., 2014; TARRAF et al., 2015). Further studies will be needed to examine this hypothesis.
Fruit size, as measured by the longitudinal and equatorial diameter, was not significantly affected by the Spirufert ${ }^{\circledR}$ treatments (Table 2). The mean values for longitudinal diameter and equatorial diameter of eggplant fruits were $120.4 \mathrm{~mm}$ and 63.6 $\mathrm{mm}$, respectively. Thus, according to the proposal for eggplant classification of the Brazilian program for the improvement of horticultural market standards and packaging, eggplant fruits in this study belonged to class 11 (longitudinal length $<140$ $\mathrm{mm}$ ) and subclass 6 (equatorial length $>60$ and $<70$ $\mathrm{mm}$ ), which meet the standard quality requirements for eggplant sale (HORTIBRASIL, 2015).

Table 2. Stem diameter (DC), plant height (PH), number of leaves (NL), number of flower buds (NFB), number of fruits per plant (NF), yield, longitudinal diameter (LD) and equatorial diameter (ED) of fruits, and contents of nitrogen $(\mathrm{N})$, phosphorus $(\mathrm{P})$, potassium $(\mathrm{K})$, and sodium $(\mathrm{Na})$ in eggplants under different fertilizer (Spirufert $\left.{ }^{\circledR}\right)$ treatments. UFCG, Pombal 2015.

\begin{tabular}{ccccc}
\hline Treatment* & SD $(\mathrm{mm})$ & PH $(\mathrm{cm})$ & NL & NFB \\
\hline M1 & $12.69 \mathrm{a}$ & $50.56 \mathrm{a}$ & $59.41 \mathrm{c}$ & $18.58 \mathrm{ab}$ \\
M2 & $12.87 \mathrm{a}$ & $54.11 \mathrm{a}$ & $66.16 \mathrm{~b}$ & $26.75 \mathrm{a}$ \\
M3 & $13.68 \mathrm{a}$ & $52.33 \mathrm{a}$ & $78.75 \mathrm{a}$ & $9.33 \mathrm{~b}$ \\
M4 & $10.4 \mathrm{a}$ & $46.75 \mathrm{a}$ & $37.41 \mathrm{~d}$ & $18.33 \mathrm{ab}$ \\
CV (\%) & 17.12 & 5.74 & 2.82 & 30.09 \\
& $\mathrm{NF}$ & Yield $(\mathrm{g}$ plant & LD & $(\mathrm{mm})$ \\
M1 & $4.22 \mathrm{ab}$ & $451.0 \mathrm{a}$ & $124.77 \mathrm{a}$ & $65.34 \mathrm{a}$ \\
M2 & $2.72 \mathrm{bc}$ & $408.44 \mathrm{ab}$ & $114.5 \mathrm{a}$ & $61.5 \mathrm{a}$ \\
M3 & $5.08 \mathrm{a}$ & $202.5 \mathrm{~b}$ & $123.78 \mathrm{a}$ & $63.5 \mathrm{a}$ \\
M4 & $1.83 \mathrm{c}$ & $257.66 \mathrm{ab}$ & $118.61 \mathrm{a}$ & $60.06 \mathrm{a}$ \\
C.V. $(\%)$ & 19.48 & 23.52 & 5.82 & 7.27 \\
& & & \\
& & $\mathrm{~N}$ & $\mathrm{P}$ & $\mathrm{K}$ \\
M1 & $26.66 \mathrm{a}$ & $21.28 \mathrm{a}$ & $0.54 \mathrm{a}$ \\
M2 & $28.0 \mathrm{a}$ & $2.75 \mathrm{a}$ & $21.07 \mathrm{a}$ & $0.66 \mathrm{a}$ \\
M3 & $28.1 \mathrm{a}$ & $2.06 \mathrm{a}$ & $22.4 \mathrm{a}$ & $0.68 \mathrm{a}$ \\
M4 & $36.5 \mathrm{a}$ & $2.88 \mathrm{a}$ & $22.78 \mathrm{a}$ & $0.48 \mathrm{a}$ \\
CV $(\%)$ & 28.49 & $3.15 \mathrm{a}$ & 12.23 & 23.22 \\
\hline
\end{tabular}

*Foliar fertilizer (Spirufert ${ }^{\circledR}$ ) treatments during eggplant development: $\mathrm{M} 1=10,15,25$, and $35 \mathrm{~g} \mathrm{~L}^{-1} ; \mathrm{M} 2=15,20,30$, and $40 \mathrm{~g}$ $\mathrm{L}^{-1} ; \mathrm{M} 3=20,25,35$, and $45 \mathrm{~g} \mathrm{~L}^{-1}$; and $\mathrm{M} 4=0 \mathrm{~g} \mathrm{~L}^{-1}$. CV: Coefficient of variation. Means followed by the same letter in a column are not significantly different (Tukey's test, $\mathrm{p}<0.05$ ). 
Foliar concentrations of N, P, K, and Na were not affected by Spirufert ${ }^{\circledR}$ treatments (Table 2 and Table 3). Similarly, Silva (2015) found no effect of increasing foliar Spirufert ${ }^{\circledR}$ concentrations on lettuce. The exchangeable levels of these elements in the soil (Table 1) were sufficiently high to offset the effects of the fertilizer treatments on the leaf contents of these elements.

Table 3. Characteristics of foliar fertilizer Spirufert ${ }^{\circledR}$ (class " $A$ " simple organic fertilizer, brand Tamanduá). UFCG, Pombal 2015.

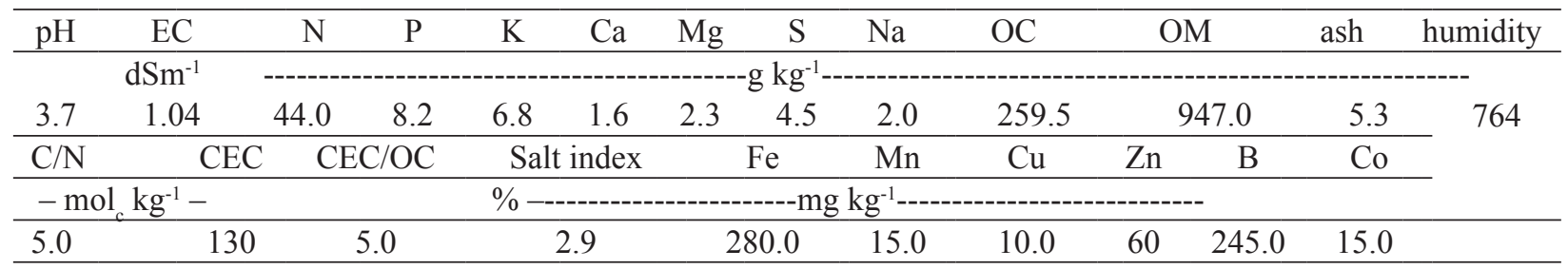

OM: organic matter; OC: organic carbon; EC: electrical conductivity.

Lightness (L*) was affected by Spirufert ${ }^{\circledR}$ treatments only at three days of storage and was significantly lower in treatment M3. There was a tendency for increased $\mathrm{L} *$ values with greater storage time within each treatment (Table 4). Hue angle
$\left(\mathrm{H}^{*}\right)$ showed a purple color typical of the species, but was not affected by Spirufert ${ }^{\circledR}$ treatments or storage times. Similarly, chroma saturation index was not affected by fertilizer treatments and showed slight variations across storage times within each treatment (Table 4).

Table 4. Lightness $\left(\mathrm{L}^{*}\right)$, hue angle $\left(\mathrm{H}^{*}\right)$, and chroma saturation index $\left(\mathrm{C}^{*}\right)$ during storage $\left(22 \pm 5^{\circ} \mathrm{C}\right.$ and $\left.55 \pm 3 \% \mathrm{RH}\right)$ of eggplant fruits produced under different foliar fertilizer (Spirufert ${ }^{\circledR}$ ) treatments. UFCG, Pombal 2015.

\begin{tabular}{|c|c|c|c|c|c|}
\hline \multirow{2}{*}{ Treatment } & \multicolumn{5}{|c|}{ Days of storage } \\
\hline & 0 & 3 & 4 & 5 & 6 \\
\hline \multicolumn{6}{|c|}{ Lightness $\left(\mathrm{L}^{*}\right)$} \\
\hline M1 & 27.05a B & 26.16ab B & 27.69a AB & $27.87 \mathrm{a} \mathrm{AB}$ & $31.83 \mathrm{a} A$ \\
\hline M2 & 26.41a B & $26.94 \mathrm{a} A B$ & $29.35 \mathrm{a} \mathrm{AB}$ & $28.4 \mathrm{a} A B$ & $30.82 \mathrm{a} \mathrm{A}$ \\
\hline M3 & $27.56 \mathrm{a} B$ & $22.59 \mathrm{~b} \mathrm{C}$ & $30.57 \mathrm{a} \mathrm{AB}$ & $29.53 \mathrm{a} A B$ & $32.69 \mathrm{a} \mathrm{A}$ \\
\hline M4 & 28.3a B & $28.06 \mathrm{a}$ B & $27.55 \mathrm{a} \mathrm{B}$ & 27.99a B & $33.96 \mathrm{a} \mathrm{A}$ \\
\hline \multicolumn{6}{|c|}{ Hue angle $\left(\mathrm{H}^{*}\right)$} \\
\hline M1 & $6.53 \mathrm{~b} \mathrm{~A}$ & $4.90 \mathrm{a} \mathrm{A}$ & $10.98 \mathrm{a} \mathrm{A}$ & $4.34 \mathrm{a} \mathrm{A}$ & $8.09 \mathrm{a} \mathrm{A}$ \\
\hline M2 & $2.93 \mathrm{~b} \mathrm{~A}$ & $9.87 \mathrm{a} \mathrm{A}$ & $7.04 \mathrm{a} \mathrm{A}$ & $6.05 \mathrm{a} \mathrm{A}$ & 5.64a A \\
\hline M3 & $20.42 \mathrm{a} \mathrm{A}$ & $6.32 \mathrm{a} \mathrm{A}$ & $14.54 \mathrm{a} \mathrm{A}$ & 7.69a A & $3.76 \mathrm{aA}$ \\
\hline M4 & 14.27ab A & $9.17 \mathrm{a} \mathrm{A}$ & $6.05 \mathrm{a} A$ & $5.95 \mathrm{a} \mathrm{A}$ & $8.22 \mathrm{a} \mathrm{A}$ \\
\hline \multicolumn{6}{|c|}{ Chroma saturation index $\left(\mathrm{C}^{*}\right)$} \\
\hline M1 & $9.3 \mathrm{a} \mathrm{A}$ & $8.89 \mathrm{a} A$ & $9.31 \mathrm{a} \mathrm{A}$ & $10.71 \mathrm{a} \mathrm{A}$ & $8.43 \mathrm{a} \mathrm{A}$ \\
\hline M2 & 8.59a AB & $7.59 \mathrm{a} B$ & $12.89 \mathrm{a} \mathrm{A}$ & $10.88 \mathrm{a} A B$ & 8.6a AB \\
\hline M3 & 5.57a C & $8.03 \mathrm{a} \mathrm{BC}$ & $12.08 \mathrm{a} \mathrm{AB}$ & $12.8 \mathrm{a} \mathrm{A}$ & $9.82 \mathrm{a} \mathrm{ABC}$ \\
\hline M4 & $8.69 \mathrm{a} \mathrm{A}$ & $8.57 \mathrm{a} \mathrm{A}$ & $9.85 \mathrm{a} \mathrm{A}$ & $9.89 \mathrm{a} A$ & $11.94 \mathrm{a} \mathrm{A}$ \\
\hline
\end{tabular}

${ }^{1} \mathrm{M} 1: 1.0 \%, 1.5 \%, 2.5 \%$, and 3.5\%; M2: 1.5\%, 2.0\%, 3.0\%, 4.0\%; M3: 2.0\%, 2.5\%, 3.5\%, and 4.5\%; M4: $0 \%$.

* Means followed by the same lowercase letter in the column and the same uppercase letter in the row are not significantly different by the Tukey's test $(\mathrm{p}<0.05)$. 
Fruit firmness was not significantly different across Spirufert ${ }^{\circledR}$ treatments at most storage times (Table 5). There were slight variations in firmness in treatments M3 and M4 during storage, which were likely caused by differences in fruit maturation at harvest. Fruit firmness was not different between treatments M1 and M2 during storage (Table 5).
Soluble solids contents were not significantly different across fertilizer treatments at most storage times but increased marginally with storage time (Table 5). Similar results were reported by Kaynas et al. (1995) and Moretti and Pineli (2005), who found increased soluble solids contents ranging from 4.2 to $5.4{ }^{\circ}$ Brix in eggplants stored under refrigeration.

Table 5. Firmness (N) and soluble solids during storage $\left(22 \pm 5^{\circ} \mathrm{C}\right.$ and $\left.55 \pm 3 \% \mathrm{RH}\right)$ of eggplant fruits produced under

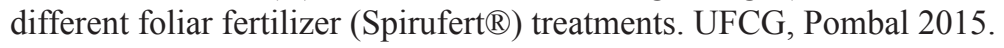

\begin{tabular}{|c|c|c|c|c|c|}
\hline \multirow[b]{2}{*}{ Treatment } & \multicolumn{5}{|c|}{ Days of storage } \\
\hline & 0 & 3 & 4 & 5 & 6 \\
\hline & \multicolumn{5}{|l|}{ Firmness (N) } \\
\hline M1 & $31.03 \mathrm{a} \mathrm{A}$ & 31.83ab A & $32.90 \mathrm{a} \mathrm{A}$ & 33.14ab A & $39.22 \mathrm{a} \mathrm{A}$ \\
\hline M2 & $36.69 \mathrm{a} A$ & $36.02 \mathrm{ab} \mathrm{A}$ & $37.17 \mathrm{a} \mathrm{A}$ & $29.86 \mathrm{~b} \mathrm{~A}$ & $30.80 \mathrm{a} A$ \\
\hline M3 & $30.64 \mathrm{a} \mathrm{B}$ & $38.98 \mathrm{a} A B$ & $33.39 \mathrm{a} A B$ & $40.42 \mathrm{a} \mathrm{A}$ & $35.20 \mathrm{a} A B$ \\
\hline \multirow[t]{2}{*}{ M4 } & 29.00a B & $30.06 \mathrm{~b} \mathrm{AB}$ & $31.55 \mathrm{a} A B$ & $38.55 \mathrm{ab} \mathrm{A}$ & $34.39 \mathrm{a} A B$ \\
\hline & \multicolumn{5}{|c|}{ Soluble solids (\%) } \\
\hline M1 & $4.23 \mathrm{a} \mathrm{B}$ & $4.77 \mathrm{a} \mathrm{A}$ & $4.83 \mathrm{a} \mathrm{A}$ & $5.03 \mathrm{aA}$ & $5.07 \mathrm{a} \mathrm{A}$ \\
\hline M2 & $4.30 \mathrm{a} B$ & $4.91 \mathrm{a} \mathrm{A}$ & $4.76 \mathrm{a} A$ & $4.80 \mathrm{a} A$ & $5.01 \mathrm{a} \mathrm{A}$ \\
\hline M3 & $4.62 \mathrm{a} \mathrm{BC}$ & $4.33 b \mathrm{C}$ & 4.77a AB & $5.12 \mathrm{a} \mathrm{A}$ & $5.05 \mathrm{a} \mathrm{A}$ \\
\hline M4 & $4.25 \mathrm{a} \mathrm{B}$ & 4.57ab AB & $4.75 \mathrm{a} \mathrm{A}$ & $4.77 \mathrm{a} \mathrm{A}$ & $4.93 \mathrm{a} \mathrm{A}$ \\
\hline
\end{tabular}

${ }^{1} \mathrm{M} 1: 1.0 \%, 1.5 \%, 2.5 \%$, and 3.5\%; M2: $1.5 \%, 2.0 \%, 3.0 \%$, and 4.0\%; M3: $2.0 \%, 2.5 \%, 3.5 \%$, and 4.5\%; M4: $0 \%$.

* Means followed by the same lowercase letter in the column and the same uppercase letter in the row are not significantly different by the Tukey's test $(\mathrm{p}<0.05)$.

\section{Conclusions}

Foliar application of Spirufert ${ }^{\circledR}$ at low concentrations (M1) increased eggplant fruit production but did not affect the leaf contents of $\mathrm{N}$, $\mathrm{P}, \mathrm{K}$, and Na. High fertilizer concentrations (M3) increased vegetative growth but reduced eggplant yield.

Color variables $\left(\mathrm{L}^{*}, \mathrm{H}^{*}\right.$, and $\left.\mathrm{C}^{*}\right)$ and soluble solids contents were not affected by the fertilizer, but pulp firmness was more stable in M1 fruits stored for up to six days at $22 \pm 5{ }^{\circ} \mathrm{C}$ and $55 \pm 3 \%$ RH.

\section{Reference}

ALY, M. S.; ESAWY, M. A. Evaluation of Spirulina platensis as bio-stimulator of organic farming systems. Journal of Genetic Engineering and Biotechnology, Cairo, v.6, n.2, p. 1-7, 2008.

ASSOCIATION OF OFFICIAL ANALYTICAL CHEMISTS - AOAC. Official Methods of Analysis of the Association of Official Analytical Chemists. $18^{\text {th }}$ ed. Gaithersburg, Maryland, 2005.

CARDOSO, M. O.; PEREIRA, W.E.; OLIVEIRA, A. P.; SOUZA, A. P. Eggplant growth as affected by bovine manure and magnesium thermophosphate rates. Scientia Agricola, São Paulo, v. 65, n. 1, p. 77-86, 2008.

CHOJNACKA, K.; SAEID, A.; MICHALAK, I. The possibilities of the application of algal biomass in the agriculture. Chemik, Poland, v. 66, n. 11, p. 1235-1248, 2012. 
DERIVI, S. C. N.; MENDEZ, M. H. M.; FRANCISON, A. D.; SILVA, C. S.; CASTRO, A. F.; LUZ, D. P. Efeito hipoglicêmico de rações à base de berinjela (Solanum melongena L.) em ratos. Ciência e Tecnologia de Alimentos, Campinas, v. 22, n. 2, p. 164-169, 2002.

EMPRESA BRASILEIRA DE PESQUISA AGROPECUÁRIA - EMBRAPA. Manual de métodos de análise de solos. Rio de Janeiro: EMBRAPA Solos, 1997. $212 \mathrm{p}$.

FERRAZZA, D.; SIMONETTI, A. P. M. M. Uso de extrato de algas no tratamento de semente e aplicação foliar, na cultura da soja. Cultivando o Saber, Cascavel, v. 3, n. 2, p. 48-57, 2010.

FERREIRA, D. F. Sisvar: um sistema computacional de análise estatística. Ciência e Agrotecnologia, Lavras, v. 35, n. 6, p. 1039-1042, 2011.

GARCIA-GONZALEZ, J.; SOMMERFELD, M. Biofertilizer and biostimulant properties of the microalga Acutodesmus dimorphus. Journal Applied Phycology, Copenhagen, v. 28, n. 2, p. 1051-1061, 2015.

GONÇALVES, M. C. R.; DINIZ, M. F. F.M.; BORBA, J. D. C; NUNES, X. P.; FILHO, J. M. B. Beringela (Solanum melongena L.) - mito ou realidade no combate as dislipidemias? Revista Brasileira de Farmacognosia, João Pessoa, v. 16, n. 2, p. 252-257, 2006.

INSTITUTO BRASILEIRO DE QUALIDADE EM HORTICULTURA - HORTIBRASIL. Proposta referente a classificação da berinjela para o programa brasileiro para a melhoria dos padrões comerciais e embalagens de hortigranjeiros. Brasília, versão on line. 2015. Available at: <www.hortibrasil.org.br/jnw/classificacao/berinjela/ arquivos/norma.html $>$. Accessed at: 15 jun. 2015.

JORGE, P. A. R.; NEYRA, L. C.; OSAKI, R. M.; ALMEIDA, E.; BRAGAGNOLO, N. Efeito da berinjela sobre os lipídeos plasmáticos, a peroxidação lipídica e a reversão da disfunção endotelial na hipercolesterolemia experimental. Arquivos Brasileiros de Cardiologia, Rio de Janeiro, v. 70, n. 2, p. 87-91, 1998.

KAYNAS, K.; ÖZELKÖK, S.; SÜMELI, N.; ABAK, K. Controlled and modified atmosphere storage of eggplant (Solanum melongena L.) fruits. Acta Horticulturae, Malaga, v. 412, n. 1, p. 143-151, 1995.

MALAVOLTA, E.; VITTI, G. C.; OliveIRA, S. A. Avaliação do estado nutricional de plantas: princípios e aplicações. Piracicaba: Potafos, 1997. 319 p.

MALDANER, I. C.; GUSE, F. I.; STRECHII, N. A.; HELDWEINII, A. B. Filocrono, área foliar e produtividade de frutos de berinjela conduzidas com uma e duas hastes por planta em estufa plástica. Ciência Rural, Santa Maria, v. 39, n. 3, p. 671-677, 2009.
MANFIO, M. Rendimento da berinjela em função de doses de $\mathrm{P}_{2} \mathrm{O}_{5}$. 2007. Dissertação (Mestrado em Agronomia) - Universidade Federal da Paraíba, Areia.

MANRICH, A.; MERMEJO, B. C.; MORAIS, J. C.; OLIVEIRA, J. E.; MATTOSO, L. H. C.; MARTINS, M. A. Determinação da composição química da Spirulina platensis. In. WORKSHOP DE NANOTECNOLOGIA APLICADA AO AGRONEGÓCIO, 8., 2014, São Carlos. Anais... São Carlos: Embrapa Instrumentação, 2014. p.116-120.

MORETTI, C. L.; PINELI, L. L. O. Qualidade química e física de berinjelas submetidas a diferentes tratamentos pós-colheita. Ciência e Tecnologia de Alimentos, Campinas, v. 25, n. 2, p. 339-344, 2005.

OLIVEIRA, J.; MÓGOR, G.; MÓGOR, A. Produtividade de beterraba em função da aplicação foliar de biofertilizante. Cadernos de Agroecologia, Porto Alegre, v. 8, n. 2, p. 1-4, 2013.

PAUDEL, Y. P.; PRADHAN, S.; PANT, B.; PRASAD, B. N. Role of blue green algae in rice productivity. Agriculture and Biology Journal of North America, Nepal, v. 3, n. 8, p. 332-335, 2012.

PINHEIRO, J. M. S. Tecnologia pós-colheita para a conservação de bananas da cultivar tropical. 2009. Dissertação (Mestrado em Produção Vegetal no Semiárido) - Universidade Estadual de Montes Claros.

PRIYADARSHANI, I.; RATH, B. Commercial and industrial applications of micro algae - a review. Journal of Algal Biomass Utln, Baripada, v. 3, n. 4, p. 89-100, 2012.

RAIGÓN, M. D.; PROHENS, J.; MUNÕZ-FALCÓN, J. E.; NUEZ, F. Comparison of eggplant landraces and commercial varieties for fruit content of phenolics, minerals, dry matter and protein. Journal of Food Composition and Analysis, Campinas, v. 21, n. 4, p. 370376, 2008.

RIBEIRO, C. S. C.; BRUCE, S.; REIFSCHNEIDER, F. J. B. Cultivo da berinjela (Solanum melongena L.). Brasília: Embrapa CNPH, 1998. 23 p.

SCHMITZ, R.; MAGRO, C. D.; COLlA, L. M. Aplicações ambientais de microalgas. Revista CIATEC $U P F$, Passo Fundo, v. 4, n. 1, p. 48-60, 2012.

SHALABY, T. A.; ELRAMADY, H. Effect of foliar application of biostimulants on growth, yield, componentes, and storability of garlic (Allium sativum L.). Australian Journal of Crop Science, v. 8, n. 2, p. 271$275,2014$. 
SILVA, D. S. O. Produção, fisiologia e qualidade póscolheita da alface Elba sob adubação foliar com Spirulina platensis. 2015. Dissertação (Mestrado em Horticultura Tropical) - Universidade Federal de Campina Grande, Pombal.

TARRAF, S. A.; TALAAT, I. M.; EL-SAYED, A. E.K. B.; BALBAA, L. K. Influence of foliar application of algae extract and amino acids mixture on fenugreek plants in sandy and clay soils. Nusantara Bioscience, Giza, v. 7, n. 1, p. 33-37, 2015.
ZODAPE, S. T.; GUPTA, A.; BHANDARI, S. C.; RAWAT, U. S.; CHAUNHARY, D. R.; ESWARAN, K.; CHIKARA, J. Foliar application of seaweed sap as biostimulant for enhacement of yield and quality of tomato (Lycopersicon esculentum Mill.). Journal of Scientific and Industrial Research, Piracicaba, v. 70, n. 3, p. 215-219, 2011. 
